\title{
"Pathways to the Cosmos - The Alignment of Megalithic Tombs in Ireland and Atlantic Europe". Dublin Castle, Ireland, 15th September, 2018
}

\author{
Liz Henty \\ University of Wales Trinity Saint David \\ lizhenty2@gmail.com
}

On 15th September, 2018, the "Pathways to the Cosmos" conference was held at Dublin Castle, a venue no less prestigious than the conference itself. Subtitled "The Alignment of Megalithic Tombs in Ireland and Atlantic Europe", this one-day event was organised by Archaeology Ireland magazine on behalf of the National Monuments Service at the Department of Culture, Heritage and the Gaeltacht and the Office of Public Works in Ireland; as such, it was a collaborative effort which involved a dedicated team of leading Irish archaeologists, working together with staff from Archaeology Ireland. Such was the response to this initiative and so great an interest in the subject that all 325 seats were sold out within a few days, with a waiting list of $70+$.

The conference theme reflected the growing concern with how past understandings of the sky may have influenced monumental culture. Of course, Ireland has a rich monumental history which includes, among many other lesser monuments, Newgrange and Knowth (both discussed below). In recent years Irish archaeologists have been at the forefront of joining the dots between monuments, landscape, the horizon, celestial movements and the culture of the monument builders. It may also be true to say that such a conference as this, where archaeologists and archaeoastronomers figuratively sat round a table and discussed such matters in broad agreement, could not have happened a few years ago. It would also be no exaggeration to regard this conference as representing a critical point in the history of archaeoastronomy, as it has healed the long divide created when archaeoastronomers and archaeologists went their separate ways in the 1970s over arguments about Alexander Thom's megalithic science (see for example Thom 1967), each dismissive of the other.

The conference was opened by the Minister of Culture, Heritage and the Gaeltacht (Irish speaking area), Josepha Madigan, who reported that it heralded a 10-year programme to investigate Irish monumental culture, to be undertaken because, as she 
explained, monuments, many of them built around astronomical alignments, "have not lost their power or purpose". Gabriel Cooney (University College Dublin) then gave the conference opening address, noting that the backbone of the conference was the December 2017 Archaeology Ireland "Winter Solstice Alignments" issue (31.4), which included an nine-page feature entitled "Facing the Sun" (Prendergast et al. 2017), and Frank Prendergast's Solar Alignment and the Irish Passage Tomb Tradition, which was published as an Archaeology Ireland Heritage Guide (Prendergast 2018).

The presentations began with Chris Scarre's (Durham University) "Children of the Sun? The European Megalithic Phenomenon". He took his title from W. J. Perry's Children of the Sun (1923) not because he agreed with Perry's hyperdiffusionist ideas, but because he thought that the Sun was particularly important to the megalithic builders. Scarre presented a brief history of archaeoastronomy, with mentions of William Stukeley, Félix Gaillard, Sir Norman Lockyer and Alexander Thom, in order to address the key issues of measuring orientations and interpreting them - because firstly we have to identify the target of an orientation and then try to work out what the orientation means. From Michael Hoskin's surveys (2001) of southern and northwestern Europe it is apparent that there is some commonality of orientations, especially in the south. However, the further north you go, and especially in Brittany and Ireland, the orientations become more scattered. Scarre briefly visited the old argument of diffusion or parallel developments, but felt that as the dating of monuments had become more accurate, it was obvious that the diffusion argument had been overturned; for example, the monuments in Brittany were older than those in Normandy or Britain, though he felt that there were some shared practices, beliefs and cosmology.

From Europe in general, Fabio Silva (University College London and University of Wales Trinity Saint David) homed in on dolmens in northern Portugal for his talk, "Through a Glass Darkly: Orientation Uncertainty, Passages and Stars in the Western Iberian Neolithic". Material remains such as pottery and polished stone tools, together with evidence of sheep and goats, has revealed a mix of pastoralism and hunter-gathering about 1000 years before the dolmens or passage tombs were built, and uniquely for this kind of monument, the insides of the chambers feature paintings. Having set the scene, Silva explained the new reflexive theory of skyscape archaeology, a methodology prefaced by a new usage of "skyscapes" coined a few years earlier. He profiled his work on the Carregal do Sal cluster of dolmens, where he experimented with a new way of measuring the tomb entrances to increase confidence in the results. By taking all points within the chamber to determine what the builders saw, he created a window of visibility for each structure. Plotting together the entire cluster narrowed down the range of azimuths common to all, making a target easier to identify. The identified target in this case was Aldebaran, which, because of its seasonality, could have provided a calendrical marker for taking sheep to the summer grazing with the return in the autumn. Aldebaran was also identified for another cluster in north Portugal, while Alnath or Antares provided targets for two more clusters in the region.

More locally, Jane Downes (University of the Highlands and Islands, Orkney) took us on a journey from the Brodgar area in Orkney to the Boyne Valley in Ireland in "From Brodgar to Boyne: A Cosmological Interpretation of the Alignments of Burial Monuments". Her 
thesis was concerned with the manipulation of light and dark as mediated by the Sun. The obvious example on Orkney is Maeshowe, where the midwinter Sun shines through the entrance to light the back of the chamber. That this was intentional seems to be in no doubt, as this ray of sunlight is only possible because the Sun shines through a notch on the side of Hoy's Ward Hill. Also on Orkney is the Taversöe Tuick Chambered Cairn, a two-storey tomb which has a passage to the southwest on the lower floor, while the top chamber faces northwards. Here the illumination is only possible because the sunlight is reflected off the sea. Both Maeshowe and Taversöe Tuick have floor drains, suggesting the possibility of light in and watery substances out. Another example of this light-anddark theme is Crantit cairn, a subterranean tomb which has a light box at ground level. There the sun shines through in an east-southeast direction in February and October, the time of the cross-quarter sunrise. There are instances too of reverse orientations where the shadows of stones or people can be thrown up at the back of the chambers. The later Bronze Age cists and cemeteries reflect a different cosmology with a mix of directions ranging from north-south, northeast-southwest and northwest-southeast. These many examples in Orkney where the Sun is given importance, Downes feels, are reflective of the builders' cosmology and "maintenance of ontological security".

In the last presentation of the morning, Richard Bradley (University of Reading) took a longer view of Britain's monumental culture with "The Prehistoric Sky, 3000 to 500 $B C^{\prime \prime}$. While concentrating mainly on Scottish sites, he proposed that those in northern England bore a resemblance to what was being built at the same time in Ireland. In the dark years when the study of archaeoastronomy was only whispered by archaeologists, Bradley always had an interest in the significance of monuments, though he felt that the Moon rather than the Sun was important for the later monuments. Looking at the relationship between Earth and sky he noted that the earliest monuments tended to be oriented to the rising Sun, though later on this focus changed to the setting Sun at the Clava Cairns, for example, where the red stones are placed in the direction of the setting Sun, while the quartz stones are towards Sun rising. Bradley remarked on the grading of the stones, a particular feature of Recumbent Stones Circles (RSCs) in northeast Scotland, where he felt there was an element of orientation to be taken into account. Similarly, he pointed to the alignment of Tomnaverie RSC to the hill of Lochnagar and other alignments at the Hill of Tuach Henge and Croft Moraig circle which he did not believe to be celestial. Bradley summed up by asking a question that would not have been asked by an archaeoastronomer, though it is certainly in the purview of a skyscape archaeologist, as to whether it was possible to reference the sky without having a monumental culture. He explained that he had experienced this in natural rock features, colours of stones and in reflections in water and so on. In this vein he mentioned the rock carvings along the north shore of Loch Tay, where a watcher could observe the passage of the Sun across the sky and see its light reflected in water. These considerations led him to question whether our modern nature/culture split can be applied to prehistory; a question that may be answered when archaeologists fully engage with the ontological turn.

With lots to think and talk about the attendees were treated to an excellent hot lunch; another example of the supreme effort that had gone into the conference 
organisation. If we were feeling slightly soporific after lunch, Frank Prendergast (Dublin Institute of Technology) called on his gift of the blarney to entertain us back to attention before presenting, "Skyscape, Culture and the Irish Passage Tomb Tradition - A Complex Legacy"; an overview of the complex legacy of Irish megalithic culture. The Irish Neolithic monuments include 414 portal tombs and 220 passage tombs, and these were complemented in the Bronze Age by 566 wedge tombs, 250 stone rows and 370 stone circles. Their locations show an avoidance of the central lowlands for the entire prehistoric period. The passage tombs are located on high ground and are significantly more clustered than the court tombs, and their axes show a preference for solstitial alignments. The best-known of these passage tombs is the Neolithic burial mound at Knowth with its two passages and cruciform chamber. Also in the Boyne Valley is the spectacular site of Newgrange, with its famous winter solstice sunrise and spectacular rock art. Various factors have been scrutinised to interpret the axial alignment of the monuments: proximity to water; the surrounding topography; sacred and societal needs; astronomy; or even the possibility that the location was chosen randomly. It is unclear whether it was the experience of entering the tomb that was important or whether it was the view outside from looking within, but it could be suggested that the tombs, with their solar alignments, encapsulate journeys to and from the underworld. As the area is a designated World Heritage site, steps are being taken to preserve the dark skies for future generations to imagine "the experience of being there".

By contrast, in "Winter Solstice at Knockroe, Co. Kilkenny", Muiris O'Sullivan focused on a single monument: the Knockroe cairn with its two passage tombs, respectively opening to the southeast and the southwest. Its significance is that it features a double winter solstice alignment where the rising Sun lights up the east passage and the setting Sun illuminates the western passage as well as a large amount of megalithic art. Although the site features a clear "axis of polarisation", alignments to the winter solstice and megalithic art, common to those monuments featured by Prendergast, O'Sullivan is of the opinion that what happens at each site is locally important, even if it mirrors what takes place at other sites. For him, what is culturally significant is the dichotomy between left and right and the contrast between light and darkness, here emphasised not only by the solstice light effects but also by quartz stones placed at the entrance of the West Tomb and the enhancement of megalithic art on a quartzite pillar which flanks the West Tomb entrance. O'Sullivan's quotation from Sir Francis Bacon, "In order for the light to shine so brightly, the darkness must be present", may encapsulate the sky culture of these megalith builders.

The last session of the afternoon was entitled "Touching the Ancestors - Three Perspectives on Bridging a 5,000-year Cultural Time Gap" and consisted of the personal reflections of non-archaeologists who reflexively shared their own interest in these monuments. It was a timely reminder that these striking material remains are not the sole domains of archaeologists or archaeoastronomers, but properly belong to the Irish people. Firstly, Clare Tuffy (Office of Public Works, Visitor Services Manager, Brú na Bóinne) in her presentation "Waiting for the Light", recounted some of the many reasons that visitors attend the Boyne Valley complex; these are often celebratory, while the long 
climb is experienced as a pilgrimage. With over 40 years' experience in guiding visitors to where they can see the Sun rise or set within the monuments themselves, she never fails to share the visitors' excitement. Access to viewing the winter solstice at Newgrange is by public lottery, with upwards of 30,000 applications each year. The visits last the six days of the solstice, for which only ten lucky people can attend each day. The photographer Ken Williams has photographed many of these experiences and, in "Art, Architecture and Astronomy in the Irish Passage Tomb Tradition", he shared many of his stunning photographs with the audience. To get a feel for the range of different experiences that these monuments can engender, what cannot be put into words in this review can be seen on his website (Williams 2018). In the course of his career Williams has tried to photograph the many solar alignments across Ireland and noticed that the movement of the Sun's path across the chambers seems just as, if not more, important than the actual alignment. Visual artist Róisín Fitzpatrick, inspired by a near death experience of seeing a line of bright blue light, started asking questions about what light means to humankind. Her presentation "inLightin ${ }^{\circledast}$ Ireland: Where Ancient Wisdom Inspires Ingenious Innovation" determined her drive to bring ancient cultural heritage to light in a way that enhances modern lives by filming alignments at key Irish megalithic sites. The audience were treated to her short film of Newgrange, which encapsulated the entire experience, and a further film of the Carrowkeel complex was shown at the end of the conference. Other work includes beautifully re-created glass installations of megalithic and La Tène art. Either side of the large conference screen was lit up by two of her panels, created from natural silks and Swarovski crystals (Fitzpatrick 2018).

Clive Ruggles (University of Leicester) brought the day to a close with his presentation "Cultural Astronomy and Cultural Heritage: A Global Perspective". His main concern is how we can preserve and protect all this wonderful heritage, not just in Britain and Ireland but globally. While on a trip to Australia to study Aboriginal culture, he noted that because there were so many stars in the sky that normal constellations could not be seen, instead it was the patches of dark sky, such as one called the Emu, that were identified in their sky lore. He therefore realised that it was important to study other perceptions of the sky, other rationalities, but this could not be achieved by astronomy alone. In short, archaeoastronomy is of no value unless it combines with archaeology and is involved in other cultural issues. He demonstrated this idea by looking at Hawaiian culture, which is based on the combination of the importance of the Pleiades, topography, the Sun and looking out towards the sea. There, astronomy is just part of the bigger picture. After many years in the field, Ruggles explained that he is now involved in UNESCO's (2018) Astronomy and World Heritage programme, which aims to safeguard cultural properties and landscapes "that transcribe the relationship between mankind and the sky".

I stated earlier that this was a historically critical conference because it represents a turning point in the study of megalithic culture where sites, landscapes and skyscapes all have their part to play. Twenty years have passed since the 1998 annual SEAC conference, that year entitled "Astronomy, Cosmology and Landscape", was held in Dublin. The title had been chosen because "the theme of landscape perception has provided one of the most important links between archaeoastronomy and recent developments in theo- 
retical archaeology, through their strong common interest in questions of cosmology and cognition" (Ruggles et al. 2001, vii). With September's present conference it seems as if Irish archaeology is coming full circle in fulfilling its theme of "Pathways to the Cosmos". There was even some overlap in the presenters, with Gabriel Cooney, Frank Prendergast and Clive Ruggles playing their part at the 1998 venue. As Ruggles $(2001,51)$ said then, archaeoastronomy is only of value if it addresses wider archaeological questions. This is of course one of the main rationales of skyscape archaeology, and the 2018 Dublin conference marks a culmination of years of effort in Ireland. Sadly, this is generally not the case elsewhere: we can only hope that British and European archaeologists and archaeoastronomers sit up and take notice.

\section{References}

Fitzpatrick, R., 2018. “Róisín Fitzpatrick, Artist of the Light ${ }^{\oplus "}$ [online]. Accessed October 2018, http://roisinfitzpatrick.com/

Hoskin, M., 2001. Tombs, Temples and Their Orientations: A New Perspective on Mediterranean Prehistory. Bognor Regis, UK: Ocarina Books.

Perry, W. J., 1923. The Children of the Sun: A Study in the Early History of Civilisation. London: Methuen.

Prendergast, F., 2018. Solar Alignment and the Irish Passage Tomb Tradition. Archaeology Ireland Heritage Guide 82. Dublin: Archaeology Ireland.

Prendergast, F., M. O'Sullivan, K. Williams and G. Cooney, 2017. "Facing the Sun". Archaeology Ireland 31 (4): 10-17.

Ruggles, C. L . N, 2001. "Astronomy, Cosmology, Monuments and Landscape in Prehistoric Ireland". In Astronomy, Cosmology and Landscape: Proceedings of the SEAC 98 Meeting, Dublin, Ireland, September 1998, edited by C. L. N. Ruggles, F. Prendergast and T. Ray, 51-71, Bognor Regis, UK: Ocarina Books.

Ruggles, C. L. N., F. Prendergast and T. Ray, eds, 2001. "Preface". In Astronomy, Cosmology and Landscape: Proceedings of the SEAC 98 Meeting, Dublin, Ireland, September 1998, edited by C. L. N. Ruggles, F. Prendergast and T. Ray. Bognor Regis, UK: Ocarina Books.

Thom, A., 1967. Megalithic Sites in Britain. Oxford: Oxford University Press.

UNESCO, 2018. "Astronomy and World Heritage Thematic Initiative" [online]. Accessed October 2018, https:// whc.unesco.org/en/astronomy/

Williams, K., 2018. "Ken Williams - Visual Media" [online]. Accessed October 2018, www.shadowsandstone $. \mathrm{com} /$ 